\title{
'Chained to the pendulum of our own mad clockwork': Science fiction, cyclicality and the new dark age during the Cold War (Miller 1974: 217)
}

Mark Jancovich, University of East Anglia

\begin{abstract}
Although science fiction of the Golden Age in the 1940s and the 1950s is often associated with narratives of progress, this article demonstrates that there was a fascination within this period with narratives of cyclicality, rather than progress, narratives in which social and scientific systems collapse back into new dark ages and/or re-emerge out of such new dark ages. Furthermore, the article explores how these narratives were mobilized in relation to the Cold War and particularly the ways in which nationalist agendas were seen as repressing the international exchange of ideas that many science fiction writers regarded as central to science. However, these stories did not simply oppose politics with science so that the former was associated with ignorance and repression and the latter with knowledge and liberation. On the contrary, these stories were preoccupied with conceptual crises, in which one system of thought was overthrown by another. In other words, these were stories of scientific revolution rather than linear progress and they often presented all systems of thought as potentially restrictive. In short, these cyclical narratives were a reminder of a challenge from which many science fiction writers believed that science could not escape, a challenge that would therefore continually reassert itself: the narratives demonstrated that scientists not only needed to take responsibility for their discoveries but also to recognize that the advancement of science did not inevitably lead to (or even go hand in hand with) social, political or cultural enlightenment.
\end{abstract}




\section{Keywords}

science fiction

science

the Cold War

political intolerance

narrative

cyclicality

enlightenment

conceptual crisis

Science fiction is usually understood as being associated with the future. The covers of science fiction novels and of academic studies of the genre often display images of spaceships, robots and alien worlds, and key critics from Darko Suvin to Adam Roberts have made 'newness' central to this conceptualization of the genre (Suvin 1979; Roberts 2000). Furthermore, most writing suggests that the genre depicts science as a force for progress and, while different science fiction texts might see progress as either positive or negative, progress is imagined as a linear process and one bound up with colonialism and the assertion of manifest destiny (see, e.g., Canavan and Link 2015; Franklin 1980; Rieder 2008; Roberts 2000; Westfahl 2000). The classic space rocket depicted in science fiction becomes a powerful image that concretizes the ability of scientific technology to provide access to new frontiers while strongly associating the process of expansion with an image of time's arrow as it moves in a linear way into the future. 
One gets a very different notion of science fiction if one approaches the genre from another angle. For example, there are numerous science fiction stories, exemplified by Philip K. Dick's The Man in the High Castle (1987; originally published 1962), that are not predominantly interested in either science or the future but simply in alternative realities. Dick's novel is not set in the future, but the present (1962), but a present that is different from Dick's own present, due to an alternative history. Nor is this alterative history the product of science: it is not a present in which Einstein did not develop the theory of relativity or in which Victorian scientists had colonized the moon. Instead, it is a present in which the Axis powers had won the Second World War and in which the United States is now an occupied country.

However, if this text challenges the notion that science fiction is necessarily about the future, there is another tradition of science fiction that complicates things still further. In one of Robert Heinlein's most revered stories, 'Universe' (1975; originally published in Astounding, May 1941, but republished as part of his novel, Orphans of the Sky, in 1963), the narrative seems to be set in a pre-modern society - a dark age. However, as its central character, Hugh Hoyland, learns during the course of the narrative, the 'Universe' that he inhabits is actually a spacecraft that has been travelling for generations and that has reverted to a pre-scientific dark age. Indeed, the 1940s and the 1950s saw the production of numerous stories about new dark ages that include Fritz Leiber's Gather, Darkness (1979; originally serialized in Astounding, May, June and July 1943, but published as a novel in 1950), Andre Norton's The Stars Are Ours (1984; originally published 1954), Leigh Brackett's The Big Tomorrow (2014; originally published 1955), John Wyndham's The Chrysalids (1975; originally published 1955) and Walter M. Miller Jr's A Canticle for Leibowitz (1974; originally published 1959). Initially, these stories seem to be set in premodern societies of the past, but these societies are soon revealed to be in the future, a future that has often rejected 
science and returned to religious prohibitions on knowledge. ${ }^{1}$ In some cases, these societies are post-apocalyptic worlds but in others, such as Heinlein's 'Universe' and Norton's The Stars Are Ours, these societies have turned against science for other reasons.

It is also significant that, while science fiction films and science fiction literature are often seen as being very different from one another, these dark age narratives (and the issues to which they relate) can also be found in numerous examples of science fiction film and television in the 1950s and the 1960s. It is one of the clear points of contact between science fiction produced in different media. For example, Planet of the Apes (Schaffner, 1968) famously features another dark age. Not only does its ape society strictly control the investigations of its scientists but this planet is also revealed to be neither an alien nor a primitive world. Instead, the planet of the apes is Earth, an Earth of the future that has been devastated by a nuclear apocalypse, a discovery that is made by its central human character, Taylor, at the end of the film, when he encounters the decaying remains of the Statue of Liberty as it rises out of the forbidden zone. If this moment has become famous, it was hardly unique within films of the period and similar concerns can be found in the first cinematic contribution to the science fiction cycle of the 1950s, Rocketship $X-M$ (Neumann, 1950), in which a spaceship travels to the Moon, only to discover that it is populated by a race of primitive monsters, monsters that turn out to be the decedents of an ancient and advanced race of creatures that had destroyed their civilization through nuclear war. As one scientist puts it: 'from atomic age to stone age'. Similarly, Teenage Caveman (Corman, 1958) features another protagonist who rejects social prohibitions on knowledge but whose search for truth reveals that his world is not a prehistoric civilization of the past but a post-apocalyptic world of the future.

Of course, these stories could be simply seen as restaging enlightenment narratives in which the value of progress is demonstrated through a continual re-enactment of the conflict 
between tradition (darkness) and modernity (enlightenment). However, there are various problems with such an account: first, the new dark age often emerges out of science in various ways (and is therefore connected with it, rather than simply being its other) and second, these stories reveal a larger fascination with narratives of cyclicality within the science fiction of the period rather than with linear narratives of progress.

Alternatively, Donald Wollheim has claimed that this pattern of 'rise and fall' is common precisely because it is inevitable:

There is only a limited number of general possibilities open to human conjecture. When all the many highly inventive minds of science-fiction writers find themselves falling again and again into similar patterns, we must perforce say that this does seem to be what all our mental computers stated as the shape of the future. (Wollheim 1971: 42)

However, this raises two problems. First, if the options are so limited, the appeal of science fiction seems unclear and, second, of course, there is at least one alternative to this pattern of rise and fall: the simple narrative of progress, with which science fiction is often associated. Indeed, rather than a simple inevitability, other critics have stressed the particularity of these narratives and have noted that many science fiction writers of the 1940s and the 1950 s were fascinated by figures such as Oswald Spengler, Arnold Toynbee and Edward Gibbons, figures who were associated with grand narratives of the rise and fall of civilizations (James 1994; Luckhurst 2005; Roberts 2005; Yaszek 2009). In other words, these critics demonstrate that this narrative is not inevitable, but rather a particular version of history and what remains unclear is why these writers were drawn to these particular versions of history, and how this fascination was compatible with ideas about scientific progress. For example, these accounts 
do not clarify why the writers of this period would be attracted to someone like Spengler, who was explicitly opposed to scientific rationality and the machine age more generally. To put it another way, the science fiction writers who were most fascinated by cyclical narratives were often those, like Robert Heinlein, Isaac Asimov or Arthur C. Clarke, who were also champions of science and technology, and their interest in cyclicality was not some minor anomaly but a crucial feature of their work, an interest that relates to a crucial intellectual problem that their fiction was often attempting to work through. ${ }^{2}$

This sense of 'working through' ideas is crucial to the science fiction of this period. As Mendlesohn claims, science fiction may be best thought of as 'an ongoing discussion' rather than as 'a body of writing from which one can expect certain plot elements and specific tropes' (2003: 1). Ironically, it is precisely this concern with 'discussion' that many see as a problem with the genre. For example, Roberts acknowledges that Asimov's 'Foundation series is much beloved by many SF fans', but also complains that it is 'almost entirely composed of dialogue, often of an expository or explicatory nature' (Roberts 2005: 197), a position that is quite different from that of Mendlesohn, for whom many stories are to be read positively as dialogues and debates between different positions within the narrative but also as being in dialogue with other stories.

The following article will then explore a range of different stories from the period and analyse them as a response to the difficult situation of science during the Cold War. ${ }^{3}$ The first section will investigate how the conflict between East and West not only destroyed the international community of science but also placed the scientist in a crucial dilemma: the scientist who did not care about the social implications of their discoveries had long been castigated as 'irresponsible' but, during the Cold War, those scientists who took a stand over the political appropriation of science were accused of enabling the enemy, whether their actions were intentional or not (Boyer 1985). In this way, the new dark age can be seen as an 
attempt to think through this dilemma. The next section, then, moves on to explore the key types of dark age present within science fiction stories and the ways in which they are related to narratives of cyclicality, while the third section specifically examines Heinlein's 'Future History' stories and Asimov's Foundation series, both of which are read as key narratives of progress but that were both fundamentally concerned cyclicality. Furthermore, instead of presenting progress as a linear process through which knowledge is accumulated and/or 'truth' is revealed, these narratives are actually preoccupied with a conceptual crisis and/or scientific revolution, in which existing intellectual systems become restrictive and need to be overthrown in favour of new ways of thinking. In the process, this position results in a collapse of the distinction between religion and science and between mystification and truth. Finally, then, the article will analyse the ways in which these narratives often refuse a simple opposition between religion and science (so central to that between tradition and modernity) but rather put them in dialogue with one another, a dialogue that is usually over the politics of science. In other words, in many narratives, science cannot evade its problems through a refusal of religion but, on the contrary, science is seen as insufficient and as requiring something beyond itself to resolve the challenges that it creates. It is for this reason that many science fiction narratives present the resolution as only being possible through a transformation of knowledge, and possibly even a transcendence of science, a position that often challenges the very distinction between that which is primitive and that which is advanced. In other words, many science fictions narratives are anything but stories of scientific progress but rather present science as constantly involving a series of persistent, inevitable and therefore recurrent challenges from which it cannot escape.

In the process, the article will focus on American writers from the Golden Age of the 1940s and the 1950s, but it will also make reference to a few British writers, such as John Wyndham and Arthur C. Clarke, who shared the same community of readers and writers of 
science fiction in a way that those from other countries did not: 'only in Britain, by the end of the 1930s, was there a regular sf magazine (and that was inspired by the American example), and was American sf beginning to be read and imitated' (James 1994: 72). In other words, these British readers and writers were part of a 'newly self-conscious world of American sf' (James 1994: 53), a world that was created through the magazines' dialogue with their readers. For example, although John Campbell was hardly the first to do so, his editorship of Astounding is often seen as particularly significant in the ways in which he 'encouraged ... feedback' from readers and so 'fostered a sense that readers could help shape the genre' (Attebery 2003: 38). He is therefore seen as having 'helped break down the barrier between professional and fan, writer and reader' (Attebery 2003: 38), and created a sense of community in which British writers and readers saw themselves as being involved. For example, Clarke is not only seen today as one of the 'Big Three' science fiction writers of this period, alongside Asimov and Heinlein, but he was publishing in the American Magazines during the period. Furthermore, when he visited the United States in 1952, American science fiction writers such as Robert Heinlein played host to him in a manner that demonstrates that it was not simply Clarke who imagined himself to be part of the American science fiction community but that key American writers (and readers) regarded him as a member too (McAleer 1992).

\section{The dilemmas of science during the Cold War}

As is illustrated by the Dark Age narratives listed earlier, many of the novels concerned with these new dark ages were concentrated in the 1950 s, a period that intensified a specific intellectual problem for science and for writers concerned with its implications. The development of nuclear weapons during the Second World War did not just threaten the world with destruction but it also fundamentally changed the nature of the scientific 
community. As Boyer and others have shown, the secrecy surrounding nuclear science fractured the international character that many considered essential to the scientific community (1985). Science was increasingly harnessed to national agendas and the international exchange of scientific ideas was replaced with secrecy and competition, a situation that many scientists and science fiction writers saw as contrary to the very nature of scientific enquiry. The late 1940s also saw an intense campaign by scientists over the regulation of nuclear science but this had effectively failed by 1950 (Boyer 1985).

The link between the failure of the scientists' campaign and the proliferation of the Dark Age narratives in science fiction is demonstrated by the opening of Norton's The Stars Are Ours, when she sketches out the historical events that led to the new dark age of her novel:

Scientific training became valued only for the aid it could render in helping art and fit a nation for war. For some time scientists and techneers of all classes were kept in a form of peonage by 'security' regulations. But a unification of scientists fostered in a secret underground movement resulted in the formation of 'Free Scientist' teams, groups of experts and specialists who sold their services to both private industry and government as research workers. Since they gave no attention to the racial, political, or religious antecedent of their members, they became truly inter-national and planet-, instead of nation-, minded - a situation both hated and feared by their employers. (Norton 1984: 5)

Norton's new dark age, then, is not a product of nuclear war but rather of the failure of this 'Free Science' movement that is destroyed by (fascistic) nationalists. The novel therefore suggests that its new dark age is not a warning about what might happen in the event of 
nuclear war but rather that the new dark age had already begun due to the ways in which science was organized in the Cold War period.

In this way, the novel explicitly raises two of the concerns that run throughout many science fiction stories of the 1940s and the 1950s: first, there was a debate about whether scientific research should be driven by the curiosity of scientists or by the needs of the societies that support them (for a particularly explicit example, see Asimov's 'The Dead Past' [(1956) 1972], originally published in Astounding [April 1956]) and, second, there was an exploration of what might happen now that science was harnessed to national projects rather than operating within an international research community where ideas could be exchanged without restriction. In this way, the new dark age can be seen as a way of thinking through the situation of science in the mid twentieth century and it registered a set of ambivalences about the proper role of the scientist.

As has been argued elsewhere, during the Cold War, cultural intellectuals sought to demonstrate responsibility by defining 'responsibility as the protection of an intellectual's “freedom" at all costs' (Ross 1989: 219; see also Jancovich 2006). In other words, by refusing to take sides in the Cold War, cultural intellectuals presented themselves as asserting their responsibility: they were defending freedom by defending the autonomy of art, and by refusing to allow it to be mobilized as propaganda in the interests of the state. Of course, this position was often used precisely to present the west as representative of freedom while the Communist block was presented as its other, the propagandist state in which art was only valued in instrumental terms (Lasch 1968).

However, the situation of western scientists during the Cold War was far more difficult than that of cultural intellectuals. The pure scientist had been seen as a problem since the publication of Mary Shelley's Frankenstein (2003: originally published 1818). Unlike cultural intellectuals, scientists who were uninterested in the social and cultural implications 
of their discoveries were seen as profoundly irresponsible - in fact, it is this irresponsibility that often underpins many 'mad scientists' found in science fiction and horror. However, in the 1940s and the 1950s, those scientists, like Einstein and Oppenheimer, who challenged the state's appropriation of science were publically vilified for overstepping their authority and were often accused of being in league with the enemy - either conscious traitors or simply unsuspecting dupes of foreign powers (Boyer 1985).

If the failure of the scientists' movement in the late 1940s intensified these concerns, the Second World War had already raised the spectre of human destructiveness that led many to doubt whether human societies could cope with the destructive powers to which science gave them access. These anxieties are summed up by Clifford Simak in 'Aesop' (originally publish in Astounding, December 1947 but also published as part of the novel, City, in 1952), and in which a robot bemoans the tragic destiny of humanity: 'For a man will invent a bow and arrow, no matter what you do' (Simak 1991: 201). Furthermore, if this story appeared after the horrors of Dresden and Hiroshima, Heinlein had already formulated the problem earlier, a short time after the splitting of the atom and before the success of the Manhattan project. In 1941, the same year that he wrote 'Universe', Heinlein published 'Solution Unsatisfactory' (1970b; originally published in Astounding, May 1941), a story that starts with the invention of an ultimate weapon, a radioactive dust that kills everything, and then proceeds to work through the logic of such a weapon, a logic that (Heinlein suggests) will logically lead to world dictatorship. Heinlein's point is not that this 'solution' was a desirable outcome but that, in a world in which governments have access to weapons against which there is no defence, world dictatorship might end up being the best of the available alternatives. Furthermore, this story was not some flight of fancy: Heinlein got the idea for the story from discussions with Robert Cornog and others, scientists who would be central to the Manhattan Project and who not only encouraged his speculations on the development of 
atomic weapons, but actively recruited him to the scientists' movement once the war was over (Patterson 2010).

Even in the late 1930s, The Cosmic Engineers (Simak 1964; originally serialized in Astounding in February, March and April of 1939) not only featured a narrative preoccupied with cyclicality, ${ }^{4}$ but a female scientist, Caroline Martin, who has spent 1000 years trapped in space for taking responsibility for her scientific discoveries:

I was a traitor [...] I refused to turn over a discovery I made that would have won the war. It would have wrecked the solar system. I told them so, but they were men of war. They were desperate men. We were losing then [...]. They condemned me to space $[\ldots]$. They put me in that shell you found me in and a war cruiser towed it out to Pluto's orbit and cut it loose. It was an old condemned craft, its machinery outmoded. They ripped out the rockets and turned it into a prison for me. (Simak 1964: 24)

Nor was science fiction the only literature that was exploring these issues at the time. 1947 had seen the American version of Brecht's Life of Galileo (1971), which explicitly used Galileo's struggles with Catholic doctrine as a metaphor for the struggle against Nazism in particular and despotism more generally.

If Brecht's play explored totalitarianism through Catholic dogma, similar issues can be found in a wide range of cultural texts and debates within the period. Of course, the Scopes trial of 1925 was still fresh in the minds of many, and not only exemplified the conflict between religious and scientific (Darwinist) accounts but also freedom of thought more generally. Freedom of thought was also central to another text that came out the year after Brecht's play - Orwell's 1984 - even if this was not presented as a conflict between 
religion and science (1984; originally published in 1949). However, in the same year, another story was published that dealt with totalitarianism and the persecution of scapegoats, Shirley Jackson's The Lottery (1949). The story concerns an annual lottery in which one person is selected for a stoning by the village, and while it seems to be set in an America of the present or of the near future, there is also an association with the supposed religious intolerance of the Puritans, not only through its persecution of scapegoats but also through its violent stoning. The image of the stoning not only evokes Biblical stonings, and hence religious persecution and intolerance, but it also features in a number of dark age science fiction narratives of the period, particularly Heinlein's 'If This Goes On' (1972; originally serialized in Astounding in 1940); Brackett's The Long Tomorrow; and Miller's A Canticle for Leibowitz. The association with Puritanism is also clear in various collections of Jackson's work that contain the story. For example, The Lottery: Adventures of the Demon Lover finishes with a commentary from Christopher Morley, who says that readers will find themselves asking whether the story is 'a history of New England, to which Old England of the seventeenth century explored all is sharpest bowel-pains' or whether it is 'a history of any organised community, even a suburban ladies club?' (1949: 224). In 1956, Jackson even published a book for children entitled The Witchcraft of Salem Village (1956).

In other words, all of these stories feature a conflict between totalitarian dogma and freedom of thought and many explicitly use the image of a dark age of religious intolerance to discuss these ideas. This is also made clear in relation to the anti-communist crusades of HUAC and Senator Joe McCarthy, which are often associated with religious persecution through references to them as 'witch-trails'. If the investigation of Alger Hiss in 1948 was a key moment in this history, its association with religious persecution was also made explicit by Arthur Miller's The Crucible (1953), which was set during the Salem Witch trials but was an overt commentary upon the anti-communist purges of the period (Miller 1981). If Warren 
Susman sees the 1950 s as a transitional period, in which some commentators began to reevaluate the Puritans, he also claims that the Puritan past had specific meanings in the 1930s and the 1940s, meanings that were still dominant in the 1950s.

For Susman, 'no other historical image, except that of the frontier, has been so crucial during the development of our culture' (1984: 41) and, while earlier stages of American history had been sympathetic to the Puritans, the first half of the twentieth century tended to see Puritanism as 'simply moralism - a phoney morality without meaningful social purpose, a break on worthwhile human instincts and desires that offered no effective system of morals that intelligent man could accept' (Susman 1984: 45). In other words, the Puritan became a figure of religious rigidity and intolerance that was used as an image of a premodern dark age that contemporary America needed to reject. For example, Susman claims that the year 1927 (only two years after the Scopes trail) was a particularly decisive one due to 'Parrington's devastating and popular attack on Puritanism as essentially foreign (an English import), as well as elitist and antidemocratic' (1984: 46). By the mid twentieth century, then, the Puritans had come to represent a past that the 'free and liberated West' needed to reject (Susman 1984: 47).

In short, religious intolerance was repeatedly used as a way of exploring totalitarianism and repression during the period. Nonetheless, rather than simply posing religion against science, or tradition against modernity, many science fiction stories of the 1940s and the 1950s opposed closed intellectual systems to open ones, or rather demonstrated that all systems ran the risk of becoming dogmatic and repressive. As Edward James puts it, 'Utopia, in American sf from Campbell to Star Trek, is generally to be avoided not because it is inherently totalitarian, but because it is static, has ceased to struggle and to progress, and hence is doomed to decay' (1994: 68). Even existing scientific ideas were no longer 'truths' in many of these stories but rather 'the current state of knowledge' and therefore ideas that 
will eventually be swept aside by new ideas and new understandings of the world. Rather than using a model of science that stressed enlightenment as a linear process of progress, many science fiction stories seemed to propose a model similar to that of Thomas Kuhn's The Structure of Scientific Revolutions (1962), which was also a product of the same period. Consequently, while many critics read these science fiction stories as pro-science, and others have seen them as anti-science; ${ }^{5}$ these stories are neither simply for nor against science. Similarly, while some have seen their celebration of exploration as colonial in character (see, e.g., Canavan and Link 2015; Franklin 1980; John Rieder 2008; Roberts 2000; Westfahl 2000), many stories actually explicitly challenged colonial ambitions. A Canticle for Leibowitz even presents 'manifest destiny' or the urge to 'go forth to conquer the stars' as a symptom of the subjugation of science by the political will and the stage that immediately precedes the apocalypse (Miller 1974: 199).

\section{Dark Ages, conceptual crisis and cyclicality}

In the 1940s and the 1950s, most of the stories about the new dark ages are concerned with theocracies, societies ruled by religion and that repress or control scientific knowledge. However, these dark ages are not all the same and tend to fall into four different types. The first are stories such as Rocketship X-M or Teenage Caveman, in which the society resembles the prehistoric past. Similarly, Earth Abides narrates the collapse of civilization that results in a return to a kind of prehistoric tribalism, although in this case the suggestion is that this may be a positive purification of a decadent modernity (Stewart 1973: originally published in 1949). Another common version of the Dark Age evokes images of the medieval period, and features religious orders that are either the Catholic Church, as in A Canticle for Leibowitz, or look like the Catholic Church, as in Gather, Darkness, in which the priesthood are clearly divorced from the common people and use ritual and spectacle to oppress their subjects. 'If 
This Goes On' also involves a corrupt and hypocritical theocracy that is similar to the ways in which the Catholic Church was represented by its critics during the Reformation. The worlds of 'Universe' and Gunner Cade (Merril and Kornbluth 1969; originally published in 1952) are also associated with the Catholic Church, although in these cases it is through the scholasticism of their priesthoods and through descriptions of the commoners as 'peasants' (Heinlein 1975: 9).

Alternatively, both The Chrysalids and The Long Tomorrow evoke the theocracy of New England Puritanism, although the religious purges in the first novel are directed against 'mutants', rather than witches, while those in the latter novel are directed against 'blasphemers': those associated with the corruption of modernity and science. Finally, the last category can be found in examples such as Clarke's Against the Fall of Night (1975; originally published 1953) and Pohl and Kornbluth's Search the Sky (1970; originally published 1954), in which societies of the future have become decadent and inward-looking, so that the solution is to open them up to alternative ways of being. Clarke's story is one that so obsessed him that he wrote 'at least five versions, of ever increasing length' between 1937 and 1946 (1975: 9). It concerns a city, Diaspar, which has machinery to service its human population, a population that never leave their city and have even hidden every means of escape. The hero, Alvin, is curious about the world beyond and finds a way of travelling to another far-away land, Lys, where the people value their rural existence and fear that contact with Diaspar will corrupt them. Finally, Alvin saves both cultures by forcing them to interact, an ending that is similar to that of Search the Sky where the colonies of Earth have become isolated from one another and from Earth. To reverse their decadence and degeneration, the hero uses a faster-than-light space ship to travel between the worlds in search of a solution. What he finds is that each world has become fixed and dogmatic, and he eventually resolves that the only solution is: 'Smash the smooth, declining curve! Cross the strains, and then 
breed them back. Let mankind become genetically wild again instead of rabbits isolated in their sterile hutches!' (Pohl and Kornbluth 1970: 170; originally published 1954). The colonies will only reverse their decadence by learning to interact with one another and so come to see their own way of life as only one option among many. Finally, a similar problem is also the subject of Asimov's The Caves of Steel (Asimov 1971b; originally published 1953) in which the human population of Earth have enclosed themselves within protective domes and now fear venturing outside, whether outside is the countryside beyond the domes; the Universe beyond the Earth; or new experiences and ideas (Asimov 1971b).

If most of these dark ages are theocracies, these narratives do not simply restage a moment of enlightenment in which religious traditionalism is overthrown by scientific knowledge but often concern moments of a conceptual crisis (in which estrangement is a kind of scientific revolution) and the dilemmas associated with these moments. In 'Universe', then, Hugh believes that the interior of the spaceship on which he lives $i s$ the 'Universe' 'The ship can't go anywhere. It is everywhere' (Heinlein 1975: 25) - and he has been brought up to believe that the surviving scientific texts are religious documents that are not to be read literally but as a series of religious metaphors. However, when he finally gains access to the forbidden control room of the spaceship, and he sees the stars spread out across the infinite reaches of space beyond the ship, Hugh is overwhelmed by the vision and his whole understanding of reality undergoes a conceptual crisis.

'Oooooh!' It was an involuntary sound, caused by his inward breath. He clutched the chair arms hard enough to break fingernails, but he was not aware of it. Nor was he afraid at the moment; there was room in his being for but one emotion. Life within the ship, alternatively harsh and workaday, had place no strain on his innate capacity to experience beauty; for the first time in his life he knew the intolerable ecstasy of 
beauty unalloyed. It shook him and hurt him, like the first trembling intensity of sex. (Heinlein 1975: 31)

However, if this is a story of estrangement, and of scientific revolution, in which one world view is shattered in favour of another; this moment of conceptual crisis is described in terms that are aesthetic and sexual (as physical pleasure and pain), not simply one of abstract mental concepts.

It is therefore also a story of innocence and experience and, like many other dark age stories, it often features a young boy's painful journey into manhood (even in cases, such as Leigh Brackett, Judith Merril and Andre Norton, where the author is female). However, as with many tales of maturity, the process is not necessarily simply pleasurable or positive. Hugh's vision 'shook and hurt him' and although he sees the experience as a positive one, he is also 'possessed of a deep sense of personal loss. He knew, subconsciously, that, having seen the stars, he would never be happy again' (Heinlein 1975: 32).

Indeed, even once Hugh has overthrown the old religious order, the new administration also refuses to permit its subjects to have access to the control room. If the reasons are no longer religious but secular, the new administration still see a conceptual crisis as inherently destabilizing to social order: 'I can't have my officers upset by disturbing ideas while I am consolidating my administration. It will [...] impair discipline' (Heinlein 1975: 89). Ironically, at the end of the novel, when Hugh and his small band of rebels flee the ship in an escape pod, and have a vision of the exterior of their former 'universe', the experience is not described in terms of scientific knowledge but of 'superstitious awe' and they also choose to deny the experience to others: 'it's a mistake to show the women. You'll scare 'em silly - they ain't even seen the stars' (Heinlein 1975: 106-07). 
The conceptual crisis caused by a vision of the stars is also central to one of Asimov's stories, 'Nightfall' (originally published in Astounding, September 1941), a story about which Asimov had ambivalent feelings: having acquired the status of a 'classic', Asimov has expressed his 'irritation at being told, over and over again, that "Nightfall" was my best story' (1971a: 10). However, despite the similarities to Heinlein's tale, 'Nightfall' is not set in a dark age of religious dogma but rather in a society with an established scientific community. Certainly, the society also includes an organization of religious fanatics but it is still predominantly secular. Nonetheless, this society exists on a planet, Lagash, that has six suns and only experiences nightfall once every 2000 years. As a result, like the hero of 'Universe', this society has never seen the stars but while, in Heinlein's story, the stars lead to enlightenment and reason, in 'Nightfall', the vision of the stars destroys civilization. Rather than ushering in the light of reason, in 'Nightfall', the vision of the stars creates unreason - the conceptual crisis is so great that it drives the population into a self-destructive frenzy.

The story is therefore set as night is about to fall but Aton, a scientist, thinks that he has solved 'one of the great mysteries' of his world, the mysterious 'history of civilization on Lagash [which] displays a cyclic character':

We've located series of civilizations, nine of them definitely, and indications of others as well, all of which have reached heights comparable to our own, and all of which, without exception, were destroyed by fire at the very height of their own culture. (Asimov 1971a: 17)

But this discovery has come too late, and the scientist knows that he cannot save himself or his civilization: 'He stared moodily at the skyline where Gamma, the brightest of the planet's 
six suns, was setting [...] he knew he would never see it again as a sane man' (Asimov 1971a: 12). As he tells a reporter, who has been sent to investigate Aton's discoveries, 'In just under four hours $[\ldots]$ civilization, as we know it, comes to an end [...]. Print that! There'll be no one to read it' (Asimov 1971a: 12). However, Aton believes that, while his discoveries cannot save himself or his civilization, 'our records, except for what we will collect today [...] will mean everything to the next cycle, and that's what must survive' (Asimov 1971a: 15). Unfortunately, as night finally falls, Aton realizes the inadequacy of the records that he has bequeathed to the next generation: 'Stars - all the stars - we didn't know at all. We didn't know anything' (Asimov 1971a: 45). He has failed to grasp the enormity of the problem, or of the Universe beyond his own experience of the six suns. And so the cycle is set to be repeated once more.

In both stories, then, the sight of the stars results in a conceptual crisis but, in 'Universe', this crisis results in rationality and knowledge and, in 'Nightfall', it results in irrationality and madness. But both stories use the image of the stars as the great transformative moment, a reference that brings these stories right back to the Copernican revolution, in which the Copernican system challenged religious systems that placed humanity and the Earth at the centre of the universe. In other words, these stories are both about the promise and danger of enlightenment. Certainly both involve the 'new' but this relates to a new experience, rather to a new technology - the stars are ancient, it is the protagonist's experience of them that is new - and the conceptual crisis that this experience produces is not simply a new thing, progress, but rather a restaging of something much older. In 'Universe', the hero discovers knowledge that had been lost and, in 'Nightfall', the vision of the stars destroys civilization and starts the cycle of history over once again.

Certainly it could be claimed that stories of progress require a narrative moment of enlightenment, or rather that stories of scientific progress require a figure of irrational 
prejudice to which science will prove the antidote. But this cannot fully explain what is going on in these stories. For example, 'Nightfall' is not a story of progress but of a conceptual crisis that results in destruction, and second, Copernicus was a figure of the Renaissance, not the enlightenment, and renaissance explicitly means 'rebirth'. In other words, these stories are not about 'progress' as a linear process but are concerned with cyclicality, and they question whether we can escape the cycle from dark age to enlightenment and back again.

\section{Openness, closure and change}

Even many of the seemingly great forward-moving, linear narratives can be seen in this light. 'Universe', for example, is part of Heinlein's larger 'Future History', a series of stories that are often seen as one of the great progress narratives in science fiction. However, this series is actually made up of repeated moments of enlightenment, followed by new dark ages and vice versa; 'Universe' (and its sequel 'Common Sense', which was originally published by Astounding in October 1941) even comes towards the end of this series. Indeed, in the second story of the series, 'Let There Be Light' (originally published in Super Science Stories in May 1940), a male and female scientist discover a source of virtually free energy but encounter attempts to suppress this knowledge due to the impact that it will have on the economy and society. The female lead therefore condemns her male co-worker for only reading scientific documents, and references George Bernard Shaw's account of the 'power of corporate industry to resist any change that might threaten their dividends' (Heinlein 1970a: 43) and to turn 'any bright young inventor' into an employee whose 'inventions belong to the corporation, and only those [discoveries] that fit into the pattern of the powersthat-be ever see the light. The rest get shelved' (Heinlein 1970a: 43). Even in cases where these corporations do not own the intellectual property, it is claimed: 
Did you ever hear of guys who had found a better, cheaper fuel than gasoline? One showed up about four years ago and proved his claims - but drowned a couple of weeks later in a swimming accident. I don't say he was murdered, but it's damn funny that they never found his formula. (Heinlein 1970a: 44)

In the next story (originally published in Astounding in June 1940), this new energy source has created a system of transportation on which society is so dependent that the technicians responsible for its operation use their position to seize power, a plot that the hero foils (Heinlein 1970d). In 'The Man Who Sold the Moon' (originally published as a novella in 1950), a business man has to use all his ingenuity to overcome the various social forces inhibiting human space travel (Heinlein 1970c) and, in 'Delilah and the Space Rigger' (originally published in Blue Book Magazine in December 1949), a woman has to overcome the prejudice of men (Heinlein 1974a): she joins an all-male crew on a space station, where the head of the crew thinks that she will disrupt things, although he is soon proved wrong. Not only does she demonstrate competence that more than equals that of her male colleagues but her presence improves working relations on the space station rather than disrupting them. ‘The Long Watch' (originally published in American Legion Magazine in December 1949) features another attempt to impose dictatorship (Heinlein 1974b) and 'If this Goes On' concerns a rebellion against a theocratic dictatorship, and one that is explicitly presented a new dark age (Heinlein 1972). If this theocracy is eventually overthrown, 'Methuselah's Children' (originally serialized in Astounding in July, August and September 1941 but expanded into novel form in 1958) is the next story in the series and features another period of tyranny in which the Howard families face persecution for their difference from other humans: the families are the product of a secret experiment in selective breeding and, as a result, enjoy remarkably long lifespans (Heinlein 1971). This story is then followed by the 
theocracy of 'Universe' and, if the rebels escape from this dark age by the end of the next story, 'Common Sense' (Heinlein 1975), these stories complete Heinlein's original conception of the series, even though he was to add further stories later in his career that form the basis for World Enough and Time (Heinlein 1973) and To Sail Beyond the Sunset (Heinlein 1987)

Even Asimov's Foundation series (originally published as a series of stories between 1942 and 1950), which is often read as another of the great progress narratives, is actually one that is explicitly concerned with cyclicality. It may tell a linear narrative, in one sense, but it is about the collapse of a great social system and the birth of a new one. It also explicitly suggests that this pattern of rise and fall is not limited to these two systems but that there have been successive cycles of history beforehand and that others will follow. The premise of the series is therefore that, while 'the First Galactic Empire had endured for tens of thousands of years', it had reached 'a state of irremediable decay and decline', a process that only the brilliant Hari Seldon, 'the last great scientist of the First Empire', was able to foresee 'against all common sense and popular belief' (Asimov 1964: 9). Using science, 'psycho-history $[\ldots]$ the quintessence of sociology', he not only predicted this collapse but 'set out to remedy the situation, to bring about a state of affairs that would restore peace and civilization in a single thousand years' through the development of 'the Seldon plan' (Asimov 1964: 9).

Some critics complain that the notion of 'psycho-history', 'the science of human behaviour reduced to mathematical equations', leaves no room for human choice and action, and that it even ends up predicting the unpredictable. As Roberts puts it:

It transpires that nothing unexpected can happen in Asimov's universe. Even the unexpected $[\ldots]$ was expected after all and Sheldon $[$ sic $]$ had prepared for its 
eventuality [...]. Indeed, where at the beginning of the work we assume that Sheldon's plan was simply to ease mankind over the break-up of the Galactic Empire, by the time of the Second Foundation is revealed we realise that his conception was grander: to put an end to historical flux altogether. (2000: 77)

However, this position misses a vital point: Asimov is insistent that 'the Seldon plan' is not a finished thing, in which everything has been already predicted but rather a method for dealing with eventualities. As one inheritor of the plan puts it:

The Seldon Plan is neither complete nor correct. Instead, it is merely the best that could be done at the time. Over a dozen generations of men have poured over the equations, worked at them, taken them apart to the last decimal place, and put them together again. They've done more than that. They watched nearly four hundred years pass against the predictions and equations, they checked reality, and they learned ... They have learned more than Seldon ever knew [...]. (Asimov 1964: 86)

Indeed, Asimov goes further: 'So he created his Foundations according to the laws of psychohistory, but who knew better than he that even those laws were relative. He never created a finished product. Finished products are for decadent minds' (1964: 60). It is therefore significant that he predicts the decline of the First Galactic Empire precisely at the moment when it seemed 'so strong' or rather at the moment when 'Human beings had forgotten that any other form of existence could be' (Asimov 1964: 9). In short, decadence, for Asimov, is the product of closed systems, systems (social or intellectual) that regard themselves as being the best possible system or even the only possible system. For Asimov, decadence is a failure to recognize that there are alternative ways of being or knowing. 
Similar positions can be found in numerous other science fiction writers of the period. For example, John Wyndham's The Chrysalids not only features another dark age but one that is explicitly concerned to preserve 'the true image of God' by rooting out mutations from its post-apocalyptic world: 'And any creature that shall seem to be human, but is not formed thus is not human. It is neither man nor woman. It is a blasphemy against the true Image of God, and hateful in the sight of God' (Wyndham 1975: 13). This society worships the norm 'BLESSED IS THE NORM' (Wyndham 1975: 18) - and puts everything that does not conform to the fire. The association with Nazism is made even more explicit through references to 'The Purity of the Race' (Wyndham 1975: 56).

The story centres on David, who along with a small group of other children, have developed telepathic powers that make them potential victims of the race purists. But his Uncle Axel offers David another way of seeing things. As Axel stresses, their society does not see itself as a rejection of the "Old people before the "Tribulation"' rather it is an attempt to emulate them. But, for him, this involves two problems. First, this society cannot be sure what 'the true image' really is (even if it actually exists) because the authorities rely on an account 'from Nicholson's Repentances - and he admits that he was writing some generations after the Tribulation came, so you find yourself wondering whether he knew he was in the true image, or whether he only thought he was' (Wyndham 1975: 63). Second, whether or not Nicholson was right, Axel questions whether any society should emulate a model from the past, irrespective of whether that model is corporeal, intellectual or social. As he puts it, rather than 'try to be like the Old People and rebuild the things that have been lost', people might instead 'try being ourselves, and build for the world that is, instead of for one that's gone' (Wyndham 1975: 79).

His position, then, is close to that of the 'New People' from 'Sealand', who eventually save the children at the end of the novel, and these 'New People' are clear that they are not 
trying to resurrect the Old World and that they are not 'pig-headedly determined to keep the Old People's standards' (Wyndham 1975: 154). Instead, like Asimov, they claim that the 'idea of completed man is the supreme vanity' (Wyndham 1975: 182); that 'life is change'; and that the 'living form defies evolution at its peril; if it does not adapt, it will be broken' (Wyndham 1975: 182). There is even a Reichian quality to their philosophy: 'Whether harsh intolerance and bitter rectitude are the armour worn over fear and disappointment, or whether they are the festival-dress of the sadist, they cover an enemy of the life-force' (Wyndham 1975: 183): 'The static, the enemy of change, is the enemy of life and therefore our implacable enemy' (Wyndham 1975: 196). Of course, as Wyndham makes clear, this is an equally harsh philosophy that accepts that change is likely to mean the extinction of that which preceded it: 'It is not pleasant to kill any creature [...] but to pretend that one can live without doing so is self-deception' (Wyndham 1975: 195). Furthermore, it is a philosophy that must also acknowledge itself to be relative or incomplete. As the New People stress, change also means that their culture will eventually be replaced: 'Sometime there will come a day when we ourselves shall have to give place to a new thing. Very certainly we will struggle against the inevitable just as these remnants of the Old People do' (Wyndham 1975: 195).

Wyndham's novel is therefore another narrative placed within a cyclical history but one in which there is little talk of progress. The philosophy of the New People is as harsh as that of that of David's own people, even if David's own people are described as simply the last decadent phase of those before the 'Tribulation' - the 'remnants of the Old People' (Wyndham 1975: 195). Certainly, the New People think that their telepathy makes them superior to the Old World, ${ }^{6}$ but they do not view themselves as an improvement but a replacement, another species that replaces an older one and will in turn be replaced in the future. Furthermore, this is precisely the conflict that faces the human characters in 
Wyndham's The Midwich Cuckoos (1971; originally published in 1957), a novel in which small colonies of telepathic children appear across the Earth and threaten to replace the human population. In both The Chrysalids and The Midwich Cuckoos, the new species threatens the older one, although these two novels present the struggle from different perspectives: if David and his friend are the heroes of The Chrysalids, the telepathic children are the enemy in The Midwich Cuckoos, where it is eventually made clear that the only way to save humanity is to exterminate these children.

\section{Dialogues, challenges and the primitivism of advanced cultures}

This sense of irreconcilable differences and impossible choices is also a feature of Leigh Brackett's The Long Tomorrow, a novel that refuses to simply oppose rational science to irrational religion. Its hero, Len, is raised in a repressive religious community that is opposed to modernity. His community not only represses science but has even passed a 'Thirteen Amendment' to the Constitution: 'No city, no town, community of more than one thousand people or two hundred buildings to the square mile shall be built or permitted to exist anywhere in the United States' (Brackett 2014: v). At the start of the novel, Len already feels restricted by his world but, when he witnesses a stoning, he rejects his community and sets out with his cousin, Esau, in search of 'Bartorstown', a mythic place where science is not repressed by religious prohibition. During the early stages of the novel, then, Bartorstown remains an ideal, something that 'is more than a place' so that whether it 'exists or not, in the ways that Piper's Run [Len's home] exists doesn't matter. Bartorstown is a way of thought' (Brackett 2014: 30). Or perhaps more accurately, it is seen as a place where one can think. As Len puts it: 'We thought it would be a place where people were different, where you could think about things and talk about them without getting into trouble' (Brackett 2014: 164). 
However, when Len eventually achieves his goal, and finds Bartorstown, it becomes clear that the novel is not a straightforward narrative of enlightenment and does not present religion as simply repressive or science as necessarily liberating. On the contrary, Len finds that knowledge (as in Genesis) is something that you cannot revoke and that Bartorstown is as restrictive as the world of Piper's Run. Certainly, Bartorstown could never have lived up to his fantasy of it, but its people are as unhappy as those in the world outside, and as frustrated by their belief system. Furthermore, Bartorstown must remain secret, given the hostility towards it from the outside, and it requires that one must commit to its community for life the penalty for leaving is death! These restrictions obviously frustrate the people of Bartorstown. Some feel pressure from the secrets that they must keep, while others find themselves dreaming about the world outside in ways that are similar to the ways that Len had dreamed of escaping to Bartorstown. One scientist even suffers a breakdown and attacks the computer system that the community has been protecting - the implication is that he is frustrated by the cold rationality of its processes. The people of Bartorstown also seem to mirror the religious fanatics of the world beyond. They are in search of a scientific solution 'solution zero' - that may be a fantasy and is referred to as a 'superstition'. Even those who remain committed to Bartorstown recognize this:

Here's something to remember, the way you remember that mob that killed Soames, and Burdette and his farmers, and the New Ishmaelites. It's this - we're fanatics too, Len. We have to be, or we'd drift away and live our own lives and let the whole business go hang. We're got a belief. Don't tangle with it. Because if you do, even I won't be able to save you. (Brackett 2014: 192) 
The irony is, then, that when Len and Esau reach Bartorstown, it is Len who finds it hard to fit in, not the more practical, Esau, who is able to repress what he knows to function within the community. In contrast, Len is far more idealistic, and experiences Bartorstown as another system of repression. He is therefore persuaded to escape to the outside world, despite the penalty for leaving the community. But the outside world offers no resolution to his problems, and the novel ends with Len resigned to an inevitable return to Bartorstown. In other words, the novel presents enlightenment as disillusionment, an association that is made explicit earlier in the novel when Len first realizes that Bartorstown cannot be like his dreams of it and he describes 'the truth' as being 'when all the dreams are torn away' (Brackett 2014: $153)$.

A Canticle for Leibowitz also refuses to oppose religion and science in simple ways and explicitly puts them in dialogue with one another. The story starts when a priest in another dark age discovers some ancient manuscripts, manuscripts that turn out to be scientific documents. His dark age turns out to be another post-apocalyptic society and the documents start a new Renaissance that ends in yet another nuclear war. If the Dark Age seems to simply repress scientific knowledge, the novel is actually more complex. On the one hand, the priests are not anti-intellectuals but have sought to preserve the relics of the past during the aftermath of the war. But this situation creates a dilemma for them. They are keepers of the flame but, as such, their protection of these relics involves both the preservation of these materials and the policing of who has access to them. The priests therefore oppose themselves to the anti-intellectual mobs after the war, who tried to destroy knowledge and stoned those associated with science, but they sometimes fear that they are becoming like those mobs: 'Now, thought the abbot, he's looking at me as if I were one of Them -whatever formless "Them" it was that drove him to solitude. Staked, stoned, and burned' (Miller 1974: 140). In this way, the novel refuses to establish a clear line of 
distinction between the church as a repressive religious order and science as liberating enquiry. Instead, the novel presents a series of dialogues about the dilemmas of knowledge. If the scientist, Thon Taddeo, accuses Abbot Dom Paulo of wanting to 'keep science cloistered' (Miller 1974: 184), the Abbot accuses Taddeo of profound moral irresponsibility: of only caring about the production of knowledge but not about its use, or even the interests of those who support his research. As Dom Paulo puts it:

But you promise to begin restoring Man's control over nature. But who will govern the use of the power to control natural forces? Who will use it? To what end? How will you hold him in check? Such decisions can still be made. But if you and your group don't make them now, others will make them for you. (Miller 1974: 184)

Or as he asserts more bluntly later: 'I can see the misunderstanding is basic! To serve God first or to serve Hannegan [the figure of political power] first - that's your choice' (Miller 1974: 185).

In this way, the novel does not present religion as simply repressive and science as simply liberating, but rather it poses the dilemma of scientific enlightenment and whether humanity can finally break free of destructive battles for power and the cyclicality that results from it:

Listen, are we helpless? Are we doomed to do it again and again and again? Have we no choice but to play the Phoenix in an unending sequence of rise and fall? Assyria, Babylon, Egypt, Greece, Carthage, Rome, the Empires of Charlemagne and the Turk. Ground to dust and plowed with salt. Spain, France, Britain, America burned into the oblivion of the centuries. And again and again and again. Are we 
doomed to it, Lord, chained to the pendulum of our own mad clockwork, helpless to halt its swing? (Miller 1974: 217)

But the novel does offer some sense of a resolution. After the bombs fall again, a dying Abbot is confronted with the possibility of something new. Throughout the third part of the novel, the Abbot has been pestered by an old mutant with two heads. If Mrs Grales is the personality associated with one of these two heads, she refers to the other head as Rachel, a personality that lies dormant throughout most of the novel. However, once the bombs have fallen, it is Mrs Grales who becomes dormant and Rachel awakens. As the dying priest confronts her, he has a revelation. If, as he had already claimed, there is no "worldly evil" except that which is introduced into the world by Man - me thee Adam us' (Miller 1974: 271), Rachel seems to represent something that is beyond (or before) 'Man':

The image of those cool green eyes lingered with him as long as life. He did not ask why God would choose to raise up a creature of primal innocence from the shoulder of Mrs. Grales, or why God gave it the preternatural gifts of Eden - those gifts which Man had been trying to seize by brute force again from Heaven since he had first lost them. He had seen primal innocence in those eyes, and a promise of resurrection. One glimpse had been a bounty, and he wept in gratitude. (Miller 1974: 276-77)

Even Arthur C. Clarke frequently returns to this problem, despite often being seen as one of the utopian writers of science fiction. For example, in 'Second Dawn' (originally published in Science Fiction Quarterly in August 1951), two species learn to work together and achieve rapid scientific success in the process. One is highly intellectual and telepathic 
but does not make tools and cannot control its physical environment. It is also looking for a way out of a cycle of conflicts that threatens its annihilation as a species. The other species is less developed intellectually but has 'wonderfully sensitive hands' that enabled it to develop simple tools from which it has developed more complex technologies for the production of 'fabrics, pottery and the use of fire' (Clarke 1954: 27). However, although the story initially seems to be a Utopian one of collaboration, and of the scientific enlightenment that results from this collaboration, it ends with ominous references to 'a challenge from which' these two species 'could not escape':

In the dark, the faint glow of dying atoms burned unwavering in the rock. It would still be burning there, scarcely dimmed, when Jeryl and Eris [the story's protagonists] had been dust for centuries. It would be only a little fainter when the civilization they were building had at last unlocked its secrets. (Clarke 1954: 41)

In this way, many of Clarke's stories pose the question of whether intelligent species can solve this 'challenge' and whether they can advance science without self-destruction. Consequently, even his most Utopian stories often present the solution as being the end of humanity, or rather humanity's transcendence into another order of being. This transcendence is exemplified by 2001: A Space Odyssey (Kubrick 1968) and can also be found in other novels such as Childhood's End (1972; originally published in 1953) and The Deep Range (1974; originally published 1957), the latter being of particular interest, given that humanity does evolve into a new species but rather transcends science though religious enlightenment it moves beyond the subject/object binaries of science so that it no longer sees the natural world as something to be dominated and controlled. 
In other words, these narratives are not simply concerned with cyclicality but offer an explicit challenge to progress as a linear process. As we have seen, in many stories, the future and the past become confused, and this is made explicit in Nigel Kneale's Quatermass and the Pit (originally transmitted as a television series in December 1958 and January 1959). The story opens when a strange craft is found buried beneath London. It seems to be an unexploded bomb from the Second World War but turns out to be something much older, a futuristic spaceship that has lain buried for millennia, a space ship built by an ancient, and now extinct, race on Mars. ${ }^{7}$ Furthermore, it is discovered that, having predicted their own extinction, this race had experimented on our ancestors, so that humanity is the product of alien science rather than Darwinian evolution. However, the dead race of scientific aliens is not only from our past but also offers an image of our possible future. In other words, the story questions the distinction between 'primitive' and 'advanced' cultures. Our inheritance from the Martians seems to be both our human intelligence and our racial intolerance. As the story's key protagonist, Professor Quatermass, warns his audience at the end of the programme, the discovery has given us

knowledge of ourselves [...] of the ancient destructive urges in us that grow more deadly as our populations increase and approach in size and complexity those of ancient Mars. Every war crisis, witch-hunt, race riot, and purge is a reminder and a warning $[\ldots]$. We are the Martians. If we cannot control the inheritance within us, this will be their second dead planet. (Kneale 1979: 188)

The advanced society of alien Mars may also be a very primitive one, and the witch-hunt may not be an archaic throwback that can simply be confined to the 'primitive' past but rather a 
warning of what may grow and gain power as civilization 'advances'. In this way, the story challenges consoling narratives of progress that make distinctions between that which is primitive and that which is advanced. At the very least, it presents 'progress' as an uneven (rather than a linear) process in which advances in our technological capabilities do not necessarily go hand in hand with social, political or even cultural enlightenment.

\section{Conclusion}

Once again, then, this text brings one back to cyclical narratives in which advanced societies destroy themselves and return to a primitive existence. It also demonstrates the way in which these narratives often questioned the distinction between the advanced and the primitive. As we have seen, then, rather than associating science with a linear narrative of progress, many key science fiction stories of the 1940s and the 1950s featured cyclical narratives that frequently featured new dark ages. Furthermore, these dark ages were part of a more general response to the Cold War and to the anti-communist crusades of the period. However, in science fiction, these dark ages did not simply present religion as a force of ignorance and repression, and science as a force for knowledge and liberation. Instead, these stories often concerned conceptual crises in which one system of thought is overthrown by a new system and, as such, they are stories of scientific revolution rather than of linear progress. For this reason, many science fiction writers explicitly presented all systems of thought as potentially restrictive and tended to privilege openness over closure, not truth over ignorance. In other words, they suggested that all systems should recognize their own limitations and acknowledge that there will other ways of being and knowing, even if they have not yet come into being.

Furthermore, these positions challenged the idea that scientific progress necessarily brought wisdom. These stories did not privilege science over religion but rather put them in 
dialogue with one another, so that scientific knowledge was seen as incomplete and that scientists were required to confront the social and political implications of their discoveries. In other words, these stories confronted the political appropriation of science during the Cold War and the dilemmas that this created for the scientific community: it not only destroyed the international community of scientists (which many regarded as crucial to the values of science) but it also demonized those scientists who even tried to question the political uses of their discoveries. In short, these cyclical narratives were a reminder of a challenge from which many science fiction writers believed that science could not escape, a challenge that would therefore continually reassert itself. It demonstrated that scientists not only needed to take responsibility for their discoveries but also to recognize that the advancement of science did not inevitably led to (or even go hand in hand with) social, political or cultural enlightenment.

\section{References}

Asimov, I. (1964), Second Foundation, St Albans: Panther.

(1971a), 'Nightfall', in Nightfall One, St Albans: Granada, pp. 11-45.

(1971b), The Caves of Steel, London: Panther.

([1956] 1972), 'The Dead Past', in Earth is Room Enough, London: Panther (originally published in Astounding, April), pp. 9-50. 
Attebery, B. (2003), 'The magazine era: 1926-1960', in E. James and F. Mendleson (eds), The Cambridge Companion to Science Fiction, Cambridge: Cambridge University Press, pp. 32-47.

Berger, H. L. (1976), Science Fiction and the New Dark Age, Bowling Green, OH: Bowling Green University Popular Press.

Bould, M., Butler, A. M., Roberts, A. and Vint, S. (eds) (2009), The Routledge Companion to Science fiction, London: Routledge.

Boyer, P. (1985), By the Bomb's Early Light: American Thought and Culture at the Dawn of the Atomic Age, New York: Pantheon.

Brackett, L. (2014), The Long Tomorrow, London: Gollancz.

Brecht, B. (1971), The Life of Galileo, London: Methuen.

Bridle, J. (2018), New Dark Age: Technology and the End of the Future, London: Verso.

Canavan, G. and Link, E. C. (2015), 'Introduction', in E. Carl Link and G. Canavan (eds), The Cambridge Guide to American Science Fiction, Cambridge: Cambridge University Press, pp. 1-13.

Clarke, A. C. (1954), ‘Second dawn', in Expedition to Earth, London: Sphere, pp. 7-41. 
(1972), Childhood's End, London: Pan, 1972.

(1974), The Deep Range, London: Pan, 1974.

(1975), The Lion of Comarre \& Against the Fall of Night, London: Corgi.

Corman, R. (1958), Teenage Caveman, US: Malibu Productions.

Dick, P. K. (1987), The Man in the High Castle, Harmondsworth: Penguin.

Franklin, H. B. (1980), Robert A. Heinlein: America as Science Fiction, New York: Oxford University Press.

Heinlein, R. (1970a), 'Let there be light', in The Man Who Sold the Moon, London: New English Library, pp. 33-48.

(1970b), 'Solution unsatisfactory', in The Worlds of Robert Heinlein, London: New English Library, pp. 92-127.

(1970c), 'The man who sold the moon', in The Man Who Sold the Moon, pp. 133-221.

(1970d), 'The roads must roll', in The Man Who Sold the Moon, pp. 49-85.

(1971), Methuselah's Children, London: NEL. 
(1972), 'If this goes on', in Revolt in 2100, London: New English Library, pp. 7-139.

(1973), Time Enough for Love, New York: Putnam.

(1974a), 'Delilah and the space rigger', in The Green Hills of Earth, London: Pan, pp. $7-18$.

(1974b), 'The long watch', in The Green Hills of Earth, pp. 36-49.

(1975), Orphans of the Sky, St Albans: Panther.

(1987), To Sail Beyond the Sunset, New York: Putnam.

Jackson, S. (1949), The Lottery: Adventures of the Demon Lover, New York: Avon. (1956), The Witchcraft of Salem Village, New York: Random House.

James, E. (1994), Science fiction in the $20^{\text {th }}$ Century, Oxford: Oxford University Press.

James, E. and Mendlesohn, F. (eds) (2003), The Cambridge Companion to Science Fiction, Cambridge: Cambridge University Press.

Jancovich, M. (2006), 'The politics of Playboy: Lifestyle, sexuality and non-conformity in American cold war culture', in D. Bell and J. Hollows (eds), Historicising Lifestyle, Farnham: Ashgate, pp. 70-87. 
Kneale, N. (1979), Quatermass and the Pit, London: Arrow.

Kubrick, S. (1968), 2001: A Space Odyssey, US: Metro-Goldwyn-Mayer.

Kuhn, T. (1962), The Structure of Scientific Revolutions, Chicago: University of Chicago Press.

Lasch, C. (1968), 'The cultural cold war: A short history of the Congress of Cultural Freedom', in B. J. Bernstein (ed.), Towards a New Past, New York: Knopf, pp. 32259.

Leiber, F. (1979), Gather, Darkness, London: New English Library.

Luckhurst, R. (2005), Science Fiction, Cambridge: Polity.

McAleer, N. (1992), Odyssey: The Authorised Biography of Arthur C. Clarke, London: Gollancz.

Mendlesohn, F. (2003), 'Introduction: Reading science fiction', in E. James and F. Mendlesohn (eds), The Cambridge Companion to Science Fiction, Cambridge: Cambridge University Press, pp. 1-12.

Merril, J. and Kornbluth, C. M. (1969), Gunner Cade, New York: Dell. 
Miller, A. (1981), The Crucible, Harmondsworth: Penguin.

Miller, Jr, W. M. (1974), A Canticle for Leibowitz, London: Corgi.

Morley, C. (1949), 'Christopher Morley says about “The Lottery”', in S. Jackson (ed.), The Lottery, New York: Avon, p. 224.

Norton, A. (1984), The Stars Are Ours, New York: Ace.

Neumann, K. (1950), Rocketship X-M, US: Lippert Pictures.

Orwell, G. (1984), 1984, Harmondsworth: Penguin.

Patterson, W. H. (2010), Robert Heinlein, In Dialogue with His Century, Volume 1, New York: Thomas Doherty.

Pohl, F. and Kornbluth, C. M. (1970), Search the Sky, Harmondsworth: Penguin.

Rieder, J. (2008), Colonialism and the Emergence of Science Fiction, Middletown: Wesleyan University Press.

Roberts, A. (2000), Science Fiction, London: Routledge.

(2005), The History of Science Fiction, London: Palgrave Macmillan. 
Ross, A. (1989), No Respect: Intellectuals and Popular Culture, New York: Routledge.

Schaffner, F. J. (1968), Planet of the Apes, US: $20^{\text {th }}$ Century Fox.

Seed, D. (1999), American Science Fiction and the Cold War, Edinburgh: Edinburgh University Press.

(ed.) (2005), A Companion to Science Fiction, New York: Blackwells.

Simak, C. (1964), The Cosmic Engineers, New York: Paperback Library.

(1991), City, London: Mandarin.

Stewart, G. R. (1973), Earth Abides, London: Corgi.

Susman, W. J. (1984), Culture as History: The Transformation of American Society in the Twentieth Century, New York: Pantheon.

Suvin, D. (1979), Metamorphoses of Science Fiction: On the Poetics and History of a Literary Genre, New Haven: Yale University Press.

Wells, H. G. (2005), The Time Machine, Harmondsworth: Penguin.

Westfahl, G. (2000), Space and Beyond: The Frontier Theme in Science Fiction, Westport: Greenwood. 
Wollheim, D. A. (1971), The Universe Makers: Science Fiction Today, London: Gollancz.

Wyndham, J. (1971), The Midwich Cockoos, Harmondsworth: Penguin.

(1975), The Chrysalids, Harmondsworth: Penguin.

Yaszek, L. (2009), 'Cultural history', in M. Bould, A. Butler, A. Roberts and S. Vint (eds), The Routledge Companion to Science Fiction, London: Routledge, pp. 194-203.

\section{Contributor details}

Mark Jancovich is professor of film and television studies at the University of East Anglia, United Kingdom. He is the author of numerous articles and books, and the founder of Scope: An Online Journal of Film Studies. He is currently the series editor (with Charles Acland) of the Berg/Continuum book series, Film Genres and the managing editor of the intellect journal, Horror Studies.

Contact:

School of Art, Media and American Studies, University of East Anglia, Norwich, NR4 7TJ, UK.

E-mail:m.jancovich@uea.ac.uk

https://orcid.org/

Notes 
${ }^{1}$ Although Berger has used the phrase 'New Dark Age' to describe science fiction as antiscientific (1976), James Bridle has used it to critique contemporary technological developments; it is being used here to capture the insistent ways in which these stories evoke images of historical 'Dark Ages’ (2018: n.pag.).

${ }^{2}$ Of course, earlier science fiction stories had imagined the fall of great civilizations, an example of which can be found in H. G. Wells' The Time Machine (2005; originally published in 1895), but while US science fiction of the 1940s and the 1950s clearly developed out of this past, it was also responding to specific historical conditions and drew on this past in historically specific ways.

${ }^{3}$ For more on science fiction in the Cold War period, see David Seed (1999). This book inevitably overlaps with this article, particularly in terms of the texts that are covered. Although it is not concerned with their cyclical narratives, but the ways in which it commented on the conflicts between the United States and the Soviet Union; the threat of nuclear war; and the cultures of surveillance and conspiracy that were associated with these developments.

${ }^{4}$ The story concerns the discovery of ruins left on Pluto by an extinct alien civilization, ruins that enable contact between the novel's human characters and the Cosmic Engineers. This contact eventually reveals that humanity was created by the extinct alien civilization, and that the futuristic world of the Cosmic Engineers is waiting for a time when humans will be ready (socially and culturally) to appropriate its scientific wonders.

${ }^{5}$ For example, Luckhurst presents science fiction as a genre that 'celebrates the liberation promised by technology' (2005: 5), while Berger claims that science fiction has largely departed from the Utopian fantasies of the nineteenth century and turned to 'dystopian visions' (1976: 4) that demonstrate an explicit 'anti-scientism' (1976: 7).

${ }^{6}$ The 
Old People [...] were only ingenious half-humans, little better than savages; all living shut off from one another, with only clumsy words to link them. Often they were shut off still more by different languages, and different beliefs [...]. There was, you see, no real communication, no understanding between them. They could, at best, be near sublime animals, but not more. (Wyndham 1975: 156)

${ }^{7}$ Indeed, the discovery of an ancient but futuristic spaceship has been repeatedly borrowed by later writers, from Michael Crichton to Stephen King, for whom this story has become one of the classic science fiction narratives of the period. Furthermore, this theme does not originate with Kneale and his story is, in this respect, similar to that of Simak's The Cosmic Engineers, even if Kneale's story offers a darker version of it. 